Original research article

\title{
Factors contributing to implicit rationing of nursing care: Qualitative responses to a survey of Slovak nurses
}

\author{
Dominika Kalánková ${ }^{1 *}$, Radka Kurucová ${ }^{1}$, Daniela Bartoníčková ${ }^{2}$, Katarína Žiaková ${ }^{1}$ \\ ${ }^{1}$ Comenius University in Bratislava, Jessenius Faculty of Medicine in Martin, Department of Nursing, Martin, Slovak Republic \\ ${ }^{2}$ Charles University in Prague, 2nd Faculty of Medicine, Department of Nursing, Prague, Czech Republic
}

\begin{abstract}
Objective: This study aimed to identify the main contributing factors to the implicit rationing of nursing care in the Slovak Republic. Design: A mixed-method study.

Methods: In our study, we included 504 registered nurses from two university hospitals and three teaching hospitals. Respondents who answered the open-ended question were involved in the further analysis. The Perceived Implicit Rationing of Nursing Care (PIRNCA) instrument was used for measuring the implicit rationing of nursing care. The open-ended question in the questionnaire was the subject of the thematic analysis in this study.

Results: Four major topics were identified regarding staffing issues, material resources, documentation, and management issues. Moreover, other problems unrelated to the issues emerged.

Conclusions: Identified factors were considered to be significant. Within our study, the emphasis was placed on three main factors which were described concerning the nursing profession. Only management can improve these conditions. Therefore we present the results for further consideration by hospital management.
\end{abstract}

Keywords: Instrument; Nurse; PIRNCA; Rationing of care; Work environment

\section{Introduction}

The phenomenon of the implicit rationing of nursing care was first defined by Schubert et al. (2007) within the frame of the RICH (Rationing in Switzerland) study as the withholding of any necessary nursing activity which was required or needed by the patient due to a lack of resources (personnel, material, time or skill-mix). Previously, the phenomenon was reported mostly in the medical literature (Herlitz, 2016; Jones, 2015; Strech and Danis, 2014) and referred to the resource allocation. In recent years, the phenomenon has become more visible and more common in nursing, especially in acute care settings, even though rationing of nursing care is a relatively new concept in the Slovak Republic compared to other foreign countries. However, in the past two years, more authors have been concerned with the issue of this phenomenon (Gurková and Jakubocová, 2017; Zeleníková et al., 2017). The phenomenon is often reported in relation to several factors (Papastavrou et al., 2014).

Most studies were concerned with staffing issues as the global problem (Aiken et al., 2001), followed by inadequate material resources, communication and interpersonal relationships (Kalisch, 2006; Kalisch et al., 2009), poor teamwork (Kalisch et al., 2011) or organizational aspects of the work environment of nurses (Hessels et al., 2015; Kirwan et al., 2013). The staffing issue seemed to be the main contributing factor to implicit rationing of nursing care as reported previously in different countries around the world (Buerhaus et al., 2007; Schubert et al., 2012). Nevertheless, the main aspects were considered to be the lack of nursing or assistive staff, the skill-mix in the care units, and ineffective delegation of specific nursing care tasks or nursing workload (Aiken et al., 2014, 2017, 2018; Ausserhofer et al., 2014; Jones, 2014; Schubert et al., 2008). As the second most reported contributing factor, material resources are associated with the financial situation of the particular workplace (Kirwan et al., 2013). It is also the subject of nursing management's decision-making when allocating these resources as well as that of nurses (Jones, 2015). The management is responsible for adequate support of the staff, primarily nursing staff in relation to education, benefits or finances (Jones, 2014, 2015; Papastavrou et al., 2014). Around the world, nurses complain about the time-consuming documentation. But in many studies it was proved that this part of the nursing process is missing, mainly in the area of discharge planning or development or updating the care plans (Dhaini et al., 2017; Zúñiga et al., 2015). Also, other factors occur, e.g., noncompliance of patients in receiving the nursing care because of their aggression or addiction, teamwork problems, problems communicating with physicians or other

\footnotetext{
* Author for correspondence: Dominika Kalánková, Comenius University in Bratislava, Jessenius Faculty of Medicine, Department of Nursing, Malá Hora 5, 03601 Martin, Slovak Republic; e-mail: kalankova1@uniba.sk http://doi.org/10.32725/kont.2019.027

Submitted: 2018-11-16 • Accepted: 2019-03-15 • Prepublished online: 2019-04-26 
members of the multidisciplinary team or others (Kalisch et al., 2011; Lepiešová et al., 2015). These are well-known factors contributing to rationing of care, but only one study (Henderson et al., 2017) described all of them in Australian nurses through qualitative responses of the MISSCARE Survey. The same method was applied in our study, using the open-ended question in the PIRNCA instrument.

Based on the evidence, we also consider these factors to be the main contributions to the implicit rationing of care. Also, in the Slovak Republic, these were confirmed in the pilot study as significant ones (Gurková and Jakubocová, 2017). Our study aimed to identify the main contributing factors to the implicit rationing of care at university and teaching hospitals in the Slovak Republic.

\section{Materials and methods}

\section{Sample}

All university and teaching hospitals across the Slovak Republic were requested to cooperate with the research. Despite that, only two university hospitals and three teaching hospitals permitted the study to be conducted and subsequently were included in it. Respondents were included if working i) as registered nurses, ii) in medical-surgical or intensive care units. Respondents who worked in pediatrics care units or obstetrics and gynecology care units were excluded. We distributed 946 questionnaires via head nurses in the selected hospitals, from which 504 were returned and analyzed (return rate -53 , $28 \%)$. Of the total respondents, 103 answered the open-ended question and were included in further analysis. Overall, 56 respondent's comments were integrated into our study.

\section{Data collection and data analysis}

The PIRNCA instrument was used to collect all the data. It measures the unfinished nursing care activities which have not been performed by the nurse within the last seven working shifts. It consists of 31 nursing care activities and the open-ended question at the end of the instrument: "Is there anything you would like to share about your ability to complete necessary nursing actions for your patients?" The collection of the data was processed from January 2018 to May 2018. Also, the permission for the translation and use of the measuring tool was obtained from the author (Jones, 2014). The translation of the instrument was conducted according to the methodology of Wild et al. (2005). The methodology consists of two particular parts. The first part refers to definitions, including the explanation of the labels used to describe all steps in the process and a description of the key actors involved in the process. The second part refers to the translation and cultural adaption process itself, which includes a further ten detailed steps. In addition, respondents who commented on the open-ended question were included in our study. The comments of the respondents were analyzed by the qualitative content analysis involving the thematic coding according to the methodology by Mayring (2014), which resulted in the logical categorization of statements as presented in the result section. The methodology process consists of eight specific steps representing the inductive category development. The mixed-method study design was applied in the study.

\section{Results}

Through the analysis of the comments, four significant themes related to the causes of the implicit rationing of nursing care were identified. As well as this, other issues unrelated to the major themes were explored too (Table 1). Major comments related to the staffing issue were excluded because this issue was the subject of another study. Our primary intent was therefore focused on other contributing factors to the implicit rationing of nursing care which should also be taken into significant attention. These were material resources, documentation, and management issues.

\begin{tabular}{|c|c|}
\hline Main themes & Subthemes \\
\hline Material resources & $\begin{array}{l}\text { Inadequate material assurance } \\
\text { Inconvenient hospital environment }\end{array}$ \\
\hline Documentation & $\begin{array}{l}\text { Time-consuming documentation } \\
\text { Information technologies }\end{array}$ \\
\hline Management issue & $\begin{array}{l}\text { Inadequate support service } \\
\text { Failing of tasks delegation }\end{array}$ \\
\hline Other issues & $\begin{array}{l}\text { Inadequate cooperation with patients } \\
\text { Aggression of patients }\end{array}$ \\
\hline
\end{tabular}

\section{Material resources}

The first major theme in our study was identified as the material resources. It seems to be a persistent problem across the selected hospitals due to the financial situation. Thirty-two statements were positive in this theme. The theme was then identified by two other subthemes - inadequate material equipment and inconvenient hospital environment.

\section{Inadequate material equipment}

The first subtheme identified in our study was inadequate material equipment. Nurses frequently linked material resources to insufficient financial support, which led to safety not being guaranteed:

"Deficiency of finances spent on the care unit equipment results in the safety of patients not being guaranteed."

Other nurses explained that the quality of the equipment influences the safety of patients:

"The number of beds at the care unit is 21 , but 10 of them are beds without the side rails; in cases where the patient needs the side rails a board is pinned to the bed, but this board is ineffective and there is the risk of a fall."

"The equipment for immobile patients is missing. The equipment is of poor quality. How can we ensure safely provided care?"

But the quality of care is also influenced by the quality of the equipment:

"For the quality of care, it is necessary to ensure the widgets like the lifting devices."

"The clinic is not suitable for patients with some limits or handicaps - there is no signalization, and also no possibility to go to the toilet using a wheelchair."

Some nurses just described the situation in their care unit:

"We do not have enough good-quality beds with side rails or convertible beds."

"Enough good-quality devices, sufficient technical equipment or better space allocation could make my work easier."

"We do not have aids or equipment! We do not have adequate beds for our patients."

"We just need high-quality devices and equipment for the nursing care provided to the patient; we also need monitoring instruments and better space allocation." 
Many nurses explained that the aids and equipment are of poor quality in general and they described as the main problem the spare beds for patients. They are old or damaged:

"The beds for patients are just uncomfortable."

"We have faulty equipment and widgets, but also IT department fails."

"We do not have side rails and toilet chairs."

\section{Inconvenient hospital environment}

The second subtheme identified in our study was inconvenient hospital environment. Many nurses illustrated problems with small rooms and more patients than the capacity allows. Two of the nurses explained:

"We have small rooms, but plenty of patients in the room, there is no space to move anywhere."

"The rooms are overcrowded - four beds in the room, travel bags and personal stuff of our patients are on the floor. There are tables and other furniture and no space left for patients!"

Also, the problem of transportation of patients was illustrated by one nurse:

"Adverse events cannot be prevented when patients are transported across the area of the old building hospital where there are holes on every pavement or path, and staff cannot influence this."

\section{Documentation}

The second major theme that emerged from the analysis was documentation. In the Slovak Republic, two ways of management of the documentation are stated - the electronic or written form. In this area, twelve statements were recorded. Time-consuming documentation and information technologies were identified as the main subthemes in this study.

\section{Time-consuming documentation}

Time-consuming documentation was identified as the first subtheme. Nurses described the significant problem area in documentation from the perspective of the need of time. They outlined the documentation as too long and sometimes also difficult:

"Too much of the documentation on the provided care is unnecessary; then I have no time to spend time with patients."

"I think, necessary nursing activity is not completing the nursing documentation but the personal care of the patients and their needs."

"A nurse will not become a more important, independent, respected or more serious person as long as she is writing more and more information into the documentation."

Another nurse said that she has no time for documentation during her shift because of the overload:

"I often write the reports for the documentation after my working hours because I could not do it earlier."

Nurses sometimes labelled the administration of measuring tools or scales as unnecessary:

"A nurse spends a lot of time with patients, but there is much more work with documentation like using the measuring tools. "

"We take care of our patients with the best intentions. Probably, we should take care of them a little bit more. However, there is a lot of paperwork related to scales, tools and other unnecessary documents which need to be completed. We should only complete records that are important for the health status of our patients."

One nurse admitted that she does not write the nursing process in the way she learned to do it at nursing school:

"If we wrote the nursing process as they taught us, every day, the nurses would be writing the whole day, and nobody would be caring for the patients."

\section{Information technologies}

The second subtheme related to the critical theme documentation was identified as information technologies. Nurses complained that they do not use the new technologies or better computers when writing records for the documentation. They would like to use newer computer or technology when documenting the nursing care:

"The computer is old, the operation itself is difficult; it takes a lot of time which could instead be given to the patients."

"Everything would be easier if we were using proper information technologies; the documentation needs to be simpler because there is still too much writing."

\section{Management issue}

The third and the last major theme identified in our study was the management issue. Management is one of the most influential factors in the work environment in hospitals, and this was also seen in our research. Nine statements were recorded. Another two subthemes emerged from the analysis - inadequate support service and failing of tasks delegation.

\section{Inadequate support service}

The first subtheme identified was inadequate support service. Nurses complained about the possibilities of further education. One nurse explained:

"The employer should allow further education to all nurses working in intensive care units."

But other problems were also emphasized:

"It is necessary to solve problems by offering the solution."

"Hospital management or another authority should solve the problems immediately."

"There is not adequate feedback from management."

One nurse also outlined the issue of the patient-nurse relationship and the need to make it visible:

"Ordinarily, it is essential to make provision for not only the patient-nurse relationship but also the demands of patient conditions that the nurse is responsible for."

\section{Failing of tasks delegation}

The second subtheme related to the major theme was the failing of tasks delegation. One of the main issues in the subtheme was an ineffective delegation of tasks:

"Ineffective delegation of tasks/patients among health-care team leads to the neglecting of problems; no one nurse dedicates herself to one patient $100 \% . "$

"A nurse cares mainly about providing dependent interventions related to the treatment or specific examinations. However, there is lack of time for communication with patients and relatives, or for educating them."

\section{Other issues}

Nurses identified several issues related to the causes of nursing care that were not associated with the themes we determined in our study. One of the issues is the aggression of patients or inadequate cooperation with patients. One nurse described the demands of nurses at the same time. She also emphasized the problems related to the collaboration and aggression of patients:

"The work of a nurse is challenging, but at the same time it is beautiful. A few patients exist who convince us that our job has some meaning. But on the other hand, a lot of patients do not care about their health; they expect miracles, behave aggressively, threaten us, complain or ask for things they can do by themselves..." 
Another nurse expressed concerns about the coordination of care provided to patients by relatives:

"It often happens that relatives interfere in the healthcare, e. g., they refuse fixation of the patient or other aspects of necessary care."

\section{Discussion}

In this study, we analyzed the answers to the open-ended question in the PIRNCA instrument: "Is there anything you would like to share about your ability to complete necessary nursing actions for your patients?" By a thematic analysis of the comments, we introduced the other three major themes - material resources, documentation, and management issues, as the main contributing factors which can affect the implicit rationing of nursing care in the university and teaching hospitals in the Slovak Republic. In our primary study, four major themes were identified. The staffing issue exceeded the framework of our study and so we excluded it. Our main goal was to focus on the other contributing factors because of their other importance to the nursing profession. The main theme of this study was identified as material resources, which was explained by two other subthemes - inadequate material assurance and inconvenient hospital environment. Both are connected with the available finances from hospital management. Old or damaged beds result in an uncomfortable hospital environment, and it is also correlated with the overall satisfaction of patients (Papastavrou et al., 2014; Schubert et al., 2009). The hospital management should solve these primary issues, even though there is a lack of evidence supporting the material resources as the contributing factors for the implicit rationing of care. Furthermore, Kalisch et al. (2009) considered insufficient material resources as one of the three main reasons for missed care. A lot more research supported the work of Kalisch in the area of missed care (e.g., Gurková and Jakubocová, 2017; Henderson et al., 2017; Hérnandez-Cruz et al., 2017). In our study, documentation was identified as the second contributing factor in the implicit rationing of nursing care. Time-consuming documentation and IT Technologies were determined as the main issues that caused the occurrence of the phenomenon. Nurses clarified that because of the paperwork they could not spend more time with patients. Time scarcity also leads to negative outcomes for patients or adverse events (Jones, 2014, 2015; Jones et al., 2014, 2016). Within the documentation, a problem with IT Technologies is noticeable, especially, old equipment or a lack of equipment altogether. Documenting the provided care is demanding but necessary, and there is also space for improvement from the perspective of hospital management. In the Slovak Republic, all healthcare facilities have the electronic system of documentation. In most cases, provision of nursing care has to be documented in paper form, so there is no difference in using the electronic documentation or the standard one. In the next step, reports are often written formally and do not fulfil the stated requirements (Ministry of Health of the Slovak Republic, 2009). Moreover, as we identified in our study, administration overloading contributes to the time scarcity, which results in a situation that nurses are forced to spend less time with their patients. Time and again, these are leading reasons for the implicit rationing of nursing care in our country. The last major issue that emerged from the analysis was the management issue. Inadequate support service from the perspective of head nurses seems to be the most significant issue to solve. A lack of support in the further education of nurses can increase patient mortality (Aik- en et al., 2011, 2014) but also the negative patient outcomes (Aiken et al., 2013, 2017, 2018). From the perspective of the employer, it is necessary to solve problems accurately because it affects the positive work environment and also teamwork. The last issue concerning the topic was failing to delegate tasks. Nurses realized the adverse effect on patients and again emphasized the issue of time scarcity, especially less time for communication with patients and relatives or their further education. Furthermore, another factor may contribute to the implicit rationing of nursing care in the Slovak Republic. Regarding hospital management, the country has been through significant changes. In the public sector, university and teaching hospitals changed the individual functions of nursing care managers. Nowadays, the Board of Directors has taken over these functions and nurses have lost their competencies in the decision-making from the perspective of the hospital management. The board solves questions of financial support or material equipment. Moreover, the loss of competencies leads to a decrease in the quality of care as a consequence of the implicit rationing of nursing care. In our study, we identified unrelated issues to the major themes but related to the cause of the implicit rationing of nursing care. These issues described the aggression of patients or inadequate cooperation with patients. According to several studies (Edward et al., 2016; Merecz et al., 2006; Pekurinen et al., 2017), the aggression of patients represents a serious global issue affecting the well-being of nurses and can be associated with the higher rates of implicit rationing of nursing care in clinical practice. On the other hand, according to Duxbury and Whittington (2005), the attitudes and behavior of nurses are also some of the triggers of patient aggression. Moreover, inadequate cooperation with patients is related to the poor communication with the healthcare professionals who are responsible for effective communication. Also, all of this was explained as the barrier to nursing, because the profession of a nurse is challenging but beautiful (Lepiešová et al., 2015).

\section{Limitations}

The open-ended question was more likely to be completed by nurses who are not affected. Another limitation of our study is the division of the research into two parts. Comments which were related to the staffing issue were the subject of another study. Other problem is that there is no similar study determining the contributing factors to the implicit rationing of nursing care worldwide. Our results cannot reflect the total findings, only the partial ones.

\section{Conclusions}

The paper summed up the reasons for the implicit rationing of nursing care in selected university and teaching hospitals in the Slovak Republic. Because the phenomenon has recently become more and more apparent in nursing care, we concentrated on nurses only. From their point of view, we have identified four major issues. Notably, we have focused our attention on three topics contributing to the implicit rationing of nursing care - material resources, documentation, and management issues, because the central theme of staffing was the subject of another study. These factors are considered to be significant for nurses. Acknowledging that the nurses pointed out the problematical issues related to the implicit rationing of nursing care, the management should now focus on these issues. On the other hand, there is also a need for the management to pay more attention to itself, because it was marked as a con- 
tributing factor to the implicit rationing of care. Also, other factors that were revealed can be changed by hospital management so that the phenomenon can be reduced to a minimal level or eliminated entirely. Through this change, nurses could then provide quality and safe care as patients require it. The identification of contributing factors to the implicit rationing of nursing care, as well as its solution, are the priority areas because of the patient safety issue which is the essential aspect of the provision of nursing care. This needs to be done by the management, even though it was considered to be one of the main contributing factors to the implicit rationing of nursing care.

\section{Conflict of interests}

The authors have no conflict of interests to declare.

\section{Acknowledgements}

The contribution was supported by the project "COST OC2015-2-20085 Rationing Missed Nursing Care: An international and multidimensional problem".

\section{Faktory prispievajúce $\mathbf{k}$ implicitne pridel'ovanej ošetrovatel'skej starostlivosti: Kvalitatívne odpovede z výskumu medzi slovenskými sestrami}

Súhrn

Ciel: Ciel'om tejto štúdie bolo identifikovat' hlavné faktory, ktoré prispievajú k implicitne pridel'ovanej ošetrovatel'skej starostlivosti v Slovenskej republike.

Dizajn: Zmiešaná štúdia.

Metódy: Do našej štúdie sme zahrnuli 504 sestier z dvoch univerzitných a troch fakultných nemocníc. Respondenti, ktorí odpovedali na otvorenú otázku boli zahrnutí do d’alšej analýzy. Nástroj The Perceived Implicit Rationing of Nursing Care (PIRNCA) bol použitý pre meranie implicitne pridel'ovanej ošetrovatel'skej starostlivosti. V tejto štúdii bola otvorená otázka v dotazníku predmetom tematickej analýzy.

Výsledky: Boli identifikované štyri hlavné témy týkajúce sa personálu, materiálového zabezpečenia, dokumentácie a manažmentu. Okrem toho sa objavili aj d'alšie problémy, ktoré sa netýkali priamo problematiky.

Záver: Identifikované faktory boli považované za významné. V rámci našej štúdie bol dôraz kladený na tri hlavné faktory, ktoré boli opísané vo vztahu k ošetrovatel'skej profesii. Tieto faktory môže zlepšit' len manažment. Preto prezentujeme výsledky vo vztahu k manažmentu nemocníc.

Kl'účové slová: nástroj; PIRNCA; pracovné prostredie; pridel'ovaná starostlivost'; sestra

\section{References}

1. Aiken LH, Cimiotti JP, Sloane DM, Smith HL, Flynn L, Neff DF (2011). The Effects of nurse staffing and nurse education on patient deaths in hospitals with different nurse work environments. Med Care 49(12): 1047-1053. DOI: 10.1097/ MLR.0b013e3182330b6e.

2. Aiken LH, Clarke SP, Sloane DM, Sochalski JA, Busse R, Clarke H, et al. (2001). Nurses' reports on hospital care in five countries. Health Aff (Millwood) 20(3): 43-53. DOI: 10.1377/ hlthaff.20.3.43.

3. Aiken LH, Sloane DM, Ball J, Bruyneel L, Rafferty AM, Griffiths P (2018). Patient satisfaction with hospital care and nurses in England: an observational study. BMJ Open 11(8): e019189. DOI: 10.1136/bmjopen-2017-019189.

4. Aiken LH, Sloane DM, Bruyneel L, Van den Heede K, Griffiths P, Busse R, et al. (2014). Nurse staffing and education and hospital mortality in nine European countries: a retrospective observational study. Lancet 383(9931): 1824-1830. DOI: 10.1016/S0140-6736(13)62631-8.

5. Aiken LH, Sloane DM, Bruyneel L, Van den Heede K, Sermeus W (2013). Nurses' reports of working conditions and hospital quality of care in 12 countries in Europe. Int J Nurs Stud 50(2): 143-153. DOI: 10.1016/j.ijnurstu.2012.11.009.

6. Aiken LH, Sloane DM, Griffiths P, Rafferty AM, Bruyneel L, McHugh M, et al. (2017). Nursing skill mix in European hospitals: cross-sectional study of the association with mortality, patient ratings, and quality of care. BMJ Qual Saf 26(7): 559-568. DOI: 10.1136/bmjqs-2016-005567.

7. Ausserhofer D, Zander B, Busse R, Schubert M, De Geest S, Rafferty AM, et al. (2014). Prevalence, patterns and predictors of nursing care left undone in European hospitals: results from the multicountry cross-sectional RN4CAST study. BMJ Qual Saf 23(2): 126-135. DOI: 10.1136/bmjqs-2013-002318.
8. Buerhaus PI, Donelan K, Elrich BT, Normal L, DesRoches C, Dittus R (2007). Impact of the nurse shortage on hospital patient care: comparative perspectives. Health Aff (Millwood) 26(3): 853-862. DOI: 10.1377/hlthaff.26.3.853.

9. Dhaini SR, Zúñiga F, Ausserhofer D, Simon M, Kunz R, De Geest S, Schwendimann R (2017). Are nursing home care workers' health and presenteeism associated with implicit rationing of care? A cross-sectional multi-site study. Geriatr Nurs 38(1): 33-38. DOI: 10.1016/j.gerinurse.2016.07.003.

10. Duxbury J, Whittington $R$ (2005). Causes and management of patient aggression and violence: staff and patient perspectives. J Adv Nurs 50(5): 469-478. DOI: 10.1111/j.13652648.2005.03426.x.

11. Edward KL, Stephenson J, Ousey K, Lui S, Warelow P, Giandinoto JA (2016). A systematic review and meta-analysis of factors that relate to aggression perpetrated against nurses by patients/relatives or staff. J Clin Nurs 25(3-4): 289-299. DOI: $10.1111 /$ jocn.13019.

12. Ministry of Health of the Slovak Republic (2009). Odborné usmernenie Ministerstva zdravotnictva Slovenskej republiky o vedení zdravotnickej dokumentácie, Guideline No. 07594/2009. [online] [cit. 2018-09-25]. Available from: http:// www.fntt.sk/dokumenty/Odborne_usmernenie_SR_o_vedeni_ zdrav_dokum_c_07594_2009_OZS̄.pdf

13. Gurková E, Jakubocová V (2017). Nedokončená ošetrovatel'ská starostlivost' - výsledky pilotného výskumu na Slovensku. In: Zborník abstraktov: Quo vadis zdravotníctvo III. Prešov, Slovensko: Fakulta zdravotnických odborov, Prešovská univerzita v Prešove, pp. 26-27.

14. Henderson J, Willis E, Blackman I, Toffoli L, Verrall C (2017). Causes of missed nursing care: qualitative responses to a survey of Australian nurses. Labour \& Industry: a journal of the social and economic relations of work 26(4): 281-297. DOI: 10.1080/10301763.2016.1257755.

15. Herlitz A (2016). The limited impact of indeterminacy for healthcare rationing: how indeterminacy problems show the 
need for a hybrid theory, but nothing more. J Med Ethics 42(1): 22-25. DOI: 10.1136/medethics-2015-102937.

16. Hernández-Cruz R, Moreno-Monsiváis MG, CheverriaRivera S, Díaz-Oviedo A (2017). Factors influencing the missed nursing care in patients from a private hospital. Rev Lat Am Enfermagem 25: e2877. DOI: 10.1590/1518-8345.1227.2877.

17. Hessels AJ, Flynn L, Cimiotti JP, Cadmus E, Gershon RRM (2015). The impact of the nursing practice environment on missed nursing care. Clin Nurs Stud 3(4): 60-65. DOI: 10.5430/ cns.v3n4p60.

18. Jones TL (2014). Validation of the perceived implicit rationing of nursing care (PIRNCA) Instrument. Nurs Forum 49(2): 77-87. DOI: 10.1111/nuf.12076

19. Jones TL (2015). A descriptive analysis of implicit rationing of nursing care: Frequency and patterns in Texas. Nurs Econ 33(3): 144-154.

20. Jones TL, Gemeinhardt G, Thomson JA, Hamilton P (2016). Measuring Unfinished Nursing Care: what to consider when choosing and scoring surveys. J Nurs Care Qual 31(1): 90-91. DOI: $10.1097 / \mathrm{NCQ} .0000000000000143$.

21. Jones TL, Hamilton P, Carryer J, Sportsman S, Gemeinhardt G (2014). International network for the study of rationalised nursing care-an overview. 2nd Annual Worldwide Nursing Conference (WNC 2014). DOI: 10.5176/2315-4330_WNC14.92.

22. Kalisch BJ (2006). Missed nursing care: A qualitative study. J Nurs Care Qual 21(4): 306-313.

23. Kalisch BJ, Landstrom G, Williams RA (2009). Missed nursing care: errors of omission. Nurs Outlook 57(1): 3-9. DOI: 10.1016/j.outlook.2008.05.007.

24. Kalisch BJ, Tschannen D, Lee KH, Friese CR (2011). Hospital variation in missed nursing care. Am J Med Qual 26(4): 291-299. DOI:10.1177/1062860610395929.

25. Kirwan M, Matthews A, Scott A (2013). The impact of the work environment of nurses on patient safety outcomes: A multilevel modelling approach. Int J Nurs Stud 50(2): 253-263. DOI: 10.1016/j.ijnurstu.2012.08.020.

26. Lepiešová M, Tomagová M, Bóriková I, Farský I, Žiaková K, Kurucová R (2015). Experience of nurses with in-patient aggression in the Slovak Republic. Cent Eur J Nurs Midw 6(3): 306-312. DOI: 10.15452/CEJNM.2015.06.0020.

27. Mayring P (2014). Qualitative content analysis: theoretical foundation, basic procedures and software solution. Klagenfurt. [online] [cit. 2018-06-14]. Available from: http://nbn-resolving. de/urn:nbn:de:0168-ssoar-395173

28. Merecz D, Rymaszewska J, Moscicka A, Kiejna A, JaroszNowak J (2006). Violence at the workplace - a questionnaire survey of nurses. Eur Psychiatry 21(7): 442-450. DOI: 10.1016/j.eurpsy.2006.01.001.
29. Papastavrou E, Andreou P, Efstathiou G (2014). Rationing of nursing care and nurse patient outcomes: a systematic review of quantitative studies. Int J Health Plann Manage 29(1): 3-25. DOI: $10.1002 / \mathrm{hpm} .2160$.

30. Pekurinen V, Willman L, Virtanen M, Kivimäki M, Vahtera J, Välimäki M (2017). Patient aggression and the wellbeing of nurses: a cross-sectional survey study in psychiatric and nonpsychiatric settings. Int J Environ Res Public Health 14(10): 1245. DOI: 10.3390/ijerph14101245.

31. Schubert M, Clarke SP, Aiken LH, De Geest S (2012). Associations between rationing of nursing care and inpatient mortality in Swiss hospitals. Int J Qual Health Care 24(3): 230-238. DOI: 10.1093/intqhc/mzs009.

32. Schubert M, Clarke SP, Glass TR, Schaffert-Witvliet B, De Geest S (2009). Identifying thresholds for relationships between impacts of rationing of nursing care and nurse- and patient-reported outcomes in Swiss hospitals: a correlational study. Int J Nurs Stud 46(7): 884-893. DOI: 10.1016/j. ijnurstu.2008.10.008.

33. Schubert M, Glass TR, Clarke SP, Aiken LH, Schaffert-Witvliet B, Sloane DM, De Geest S (2008). Rationing of nursing care and its relationship to patient outcomes: the Swiss extension of the International Hospital Outcomes Study. Int J Qual Health Care 20(4): 227-237. DOI: 10.1093/intqhc/mzn017.

34. Schubert M, Glass TR, Clarke SP, Schaffert-Witvliet B, De Geest $S$ (2007). Validation of the Basel extent of rationing of nursing care instrument. Nurs Res 56(6): 416-424. DOI: 10.1097/01.NNR.0000299853.52429.62.

35. Strech D, Danis M (2014). How can bedside rationing be justified despite coexisting inefficiency? The need for 'benchmarks of efficiency'. J Med Ethics 40(2): 89-93. DOI: 10.1136/medethics-2012-100769.

36. Wild D, Groove A, Martin M, Eremenco S, McElroy S, VerjeeLorenz A, Erikson P (2005). Principles of good practice for the translation and cultural adaptation process for patient-reported outcomes (PRO) measures: report of the ISPOR task force for translation and cultural adaptation. Value Health 8(2): 94-104. DOI: 10.1111/j.1524-4733.2005.04054.x.

37. Zeleníková R, Gurková E, Jarošová D (2017). Pridel'ovaná chýbajúca starostlivost': konceptuálne a metodologické aspekty. In: Zborník abstraktov: Quo vadis zdravotníctvo III. Prešov, Slovensko: Fakulta zdravotnických odborov, Prešovská univerzita v Prešove, pp. 56-57.

38. Zúñiga F, Ausserhofer D, Hamers JP, Engberg S, Simon M, Schwendimann R (2015). The relationship of staffing and work environment with implicit rationing of nursing care in Swiss nursing homes - A cross-sectional study. Int J Nurs Stud 52(9): 1463-1474. DOI: 10.1016/j.ijnurstu.2015.05.005. 